\title{
The phenotypic plasticity of wing size in Drosophila melanogaster: the cellular basis of its genetic variation
}

\author{
G. H. DE MOED*, G. DE JONG \& W. SCHARLOO \\ Population Genetics, Department of Plant Ecology and Evolutionary Biology, Utrecht University, Padualaan 8 , \\ $\mathrm{NL}-3584 \mathrm{CH}$ Utrecht, The Netherlands
}

\begin{abstract}
The reaction norms in Drosophila melanogaster of thorax length, wing length and cell size were determined for 28 isofemale lines from three populations to investigate the role of cell size in determining the response of body size to temperature during the preimaginal stages. Both overall level and plasticity of the reaction norms of thorax length and wing length are highly correlated, leading to a relatively constant wing-thorax ratio between lines. Genetic differences in overall level of wing size reaction norms are mainly caused by differences in cell number. The response of wing size to temperature consists of changes in cell size and, to a lesser extent, cell number. The cellular basis of genetic differences in plasticity shows a transition point at an intermediate level. In steeper reaction norms, genetic differences in plasticity result from differences in the plasticity of cell size, whereas less steep reaction norms only differ in the plasticity of cell number. A significant partial correlation between wing length plasticity and cell size plasticity, correcting for thorax length plasticity, indicates a role of cell size in determining the wing-thorax ratio.
\end{abstract}

Keywords: developmental constraint, Drosophila melanogaster, plasticity, reaction norm, temperature.

\section{Introduction}

Wing size in Drosophila melanogaster is determined by the size and number of its constituent cells. Environmental conditions during development that affect wing size do so by modifying cell size, cell number or both. Similarly, genetic variation in wing size implies genetic variation in cell size and/or cell number. The question is whether genetic variation in the response of wing size to the environment is always based upon the same patterns in cell size and cell number. Interactions between cell size and cell number may reflect underlying mechanisms generating wing size.

Increased temperatures during larval and pupal development lead to a reduction of wing size in $D$. melanogaster (e.g. David et al., 1983). Natural selection experiments under laboratory conditions indicate that temperature acts as a selective agent, causing selection for a larger body size at lower temperatures (e.g. Anderson, 1966; Partridge et al., 1994). Temperature-mediated selection appears to

*Correspondence. E-mail: g.dejong@boev.biol.ruu.nl. be responsible for the widely observed clinal variation in wing size in natural populations. Populations from higher latitudes show a larger wing size at any temperature (e.g. Coyne \& Beecham, 1987; Capy et al., 1993; James et al., 1995). The response to temperature-mediated selection leads mainly to changes in the overall level of the norms of reaction but not to consistent changes in their slope, i.e. in plasticity (e.g. Tantawy \& Mallah, 1961; Coyne \& Beecham, 1987; Partridge et al., 1994). The genetic differences in wing size between populations parallel the phenotypic effects of the local environment, i.e. show co-gradient variation (sensu Levins, 1968). If a reaction norm showed the optimal sizes for all temperature conditions, an identical reaction norm would be observed in all populations rather than co-gradient variation (Berven et al., 1979). The relatively shallow response of wing size to larval temperature compared with the optimal response suggests suboptimal wing sizes at other than the local mean temperature.

Genetic variation in the plasticity of wing size is present within populations (David et al., 1994; Noach et al., 1996), allowing a response to selection 
(Scheiner \& Lyman, 1991). Given the existence of genetic variation in the plasticity of wing size, one would not expect the observed limited variation in slope between populations. This calls for a better understanding of the mechanisms determining wing size.

The overall level of the reaction norm of wing size is determined mainly by the number of cells (Robertson, 1959; James et al., 1995). Many studies have shown an effect of temperature on cell size (Alpatov, 1930; Robertson, 1959; Masry \& Robertson, 1979; Cavicchi et al., 1985; Kuo \& Larsen, 1987; Partridge et al., 1994). However, the number of cells has been described as unaffected by temperature (Robertson, 1959; Partridge et al., 1994) but has also been found to be reduced by higher temperatures (Alpatov, 1930; Cavicchi et al., 1985). The cellular basis of wing size plasticity therefore deserves further study to elucidate its mechanistic basis, which might pose a constraint on the response to selection (Maynard Smith et al., 1985; Scharloo, 1987, 1990).

In this study, patterns in the cellular basis of genetic variation in plasticity were sought in 28 isofemale lines from three populations. The genetic variation in wing size reaction norm is described and wing size variation is connected with the variation in its cellular components. How plasticity in wing size is made possible by plasticity in cell size and in cell number is examined. Finally, the relation between the wing-thorax ratio and the cellular composition of the wing is explored.

\section{Materials and methods}

\section{Lines}

Fertilized females were collected in Montpellier, France, and Houten, The Netherlands, by the authors, and in Nijengzi, Tanzania, by Dr J. J. M. van Alphen of Leiden University, The Netherlands. Isofemale lines were kept on standard corn meal medium at $17.5^{\circ} \mathrm{C}$ for \pm 30 generations before the start of the experiment. Ten lines from the Dutch population, used in an earlier experiment (G. H. de Moed et al., unpublished observations), six lines from the French population and five lines from the Tanzanian population were used. Two other French lines and five other Tanzanian lines from the original collection were observed 2 years later.

\section{Experimental conditions}

Lines were transferred to a Mittler-Bennet diet (56 $\mathrm{g}$ of dead yeast, $54 \mathrm{~g}$ of sucrose, $19 \mathrm{~g}$ of agar and 1 $\mathrm{mg}$ of nipagine in $1 \mathrm{~L}$ of tap water) at $25^{\circ} \mathrm{C}$ three generations before the start of the experiment to reduce acclimatization effects. Larvae were grown at three temperatures $\left(17.5^{\circ} \mathrm{C}, 22.5^{\circ} \mathrm{C}\right.$ and $\left.27.5^{\circ} \mathrm{C}\right)$ under food-limited axenic conditions ( $20 \mathrm{~g}$ of dead yeast, $20 \mathrm{~g}$ of sucrose, $10 \mathrm{~g}$ of agar and $1 \mathrm{mg}$ of nipagine in $1 \mathrm{~L}$ of demineralized water), under which conditions variation in wing size plasticity is larger than under optimal food conditions $(G$. H. de Moed et al., unpublished observations). Eggs were sterilized in a 3 per cent hypochlorite solution for 15 min (Sang, 1956) and transferred to $30-\mathrm{mL}$ vials containing $5 \mathrm{~mL}$ of medium with 30 eggs per vial. For each temperature, three replicate vials were used. From each replicate vial, five females were taken at random.

\section{Morphology and cell size}

The right wing from each female was mounted on a microscope slide and embedded in euparal. Thorax length was measured from the tip of the scutellum to the anterior margin of the scutum, viewed from the dorsal side. Wing length was measured from the anterior crossvein to the distal end of the third vein. Both wing length and thorax length were measured using a Reflex 3-D measurement microscope, accurate to $\pm 5 \mu \mathrm{m}$.

Cell size was measured by counting the number of trichomes in a fixed area on the dorsal wing surface of the mounted wings. Each bristle exactly corresponds with one epidermal cell (Dobzhansky, 1928). The number of bristles was counted in a $0.0142-\mathrm{mm}^{2}$ area between the third and fourth vein opposite the posterior crossvein. Bristles were counted using an IBAS image analyser. Because shape differences are generally small (data not shown), wing area could be estimated by taking the squared wing length. Cell number was estimated by dividing wing area by the average cell size at the census area, leading to:

$\ln ($ wing area $)=\ln ($ cell number $)+\ln ($ cell size $)$.

\section{Analysis of reaction norms}

All data were In-transformed to analyse the allometry between wing area and its two cellular components. The plasticity of a character was determined as the slope of the linear regression of log-transformed vial means on temperature, reflecting the relative change in size per ${ }^{\circ} \mathrm{C}$. The size at $22.5^{\circ} \mathrm{C}$, estimated by linear regression, was taken as 
a measure of the overall level of the norm of reaction, which will be referred to as the overall level of a character.

Analysis of variance was performed using a mixed model design, taking temperature and population as a fixed effect and lines as random effects (Sokal \& Rohlf, 1981). All statistical analyses were performed using SPSS/PC + version 5.01 (SPSS Inc., 1992).

\section{Results}

\section{Morphological response}

First, the genetic variation in the norms of reaction of wing size and thorax length, to which cell size has to relate, will be described. The morphological response shows some marked differences between the two sets of lines (see below). Thus, this paper will concentrate on the analysis of the initial set of 21 isofemale lines. However, the conclusions from this analysis largely hold for the additional seven lines.

The mean responses of wing length and thorax length to temperature are shown in Fig. 1 for each population. Larval temperature has a major effect on wing length (Table 1), causing a reduction in wing length with increased temperature. The response of thorax length to temperature differs from that of wing size, showing a maximal size at intermediate temperatures.

Populations differ significantly in wing length and, to a lesser extent, thorax size (Table 1). The Tanzanian population generally shows a smaller wing length compared with the Dutch and French populations. However, the wing-thorax ratio (W/T ratio) does not differ significantly between populations (Table 1).

Substantial genetic variation in wing length and thorax length was observed between lines within populations (Table 1). Both characters show significant genetic variation in plasticity, i.e. the linear component of the reaction norm (ANCOVA, temp $\times$ line interaction with temperature as a covariable; wing length: $F_{18,116}=4.80, P<0.001$; thorax length: $F_{18,116}=4.34, P<0.001$ ).

Genetic variation in the reaction norms of wing size and thorax size was further analysed by determining the overall level and the plasticity of the reaction norm of each line for each character (see Materials and methods). Overall wing length and thorax length are genetically correlated over lines $(r=0.867, P<0.001 ;$ Fig. 2a). Differences in the general size of the animal are a main factor leading to overall wing size differences. However, the significant genetic variation in the $\mathrm{W} / \mathrm{T}$ ratio (Table 1 ) shows that genetic variation in wing size is partly independent of thorax size. Similarly, the plasticity in wing length and in thorax length are genetically correlated $(r=0.790, P<0.001$; Fig. 2b). However, significant genetic variation could be shown in the plasticity of the W/T ratio $\left(F_{18,116}=5.36, P<0.001\right)$.
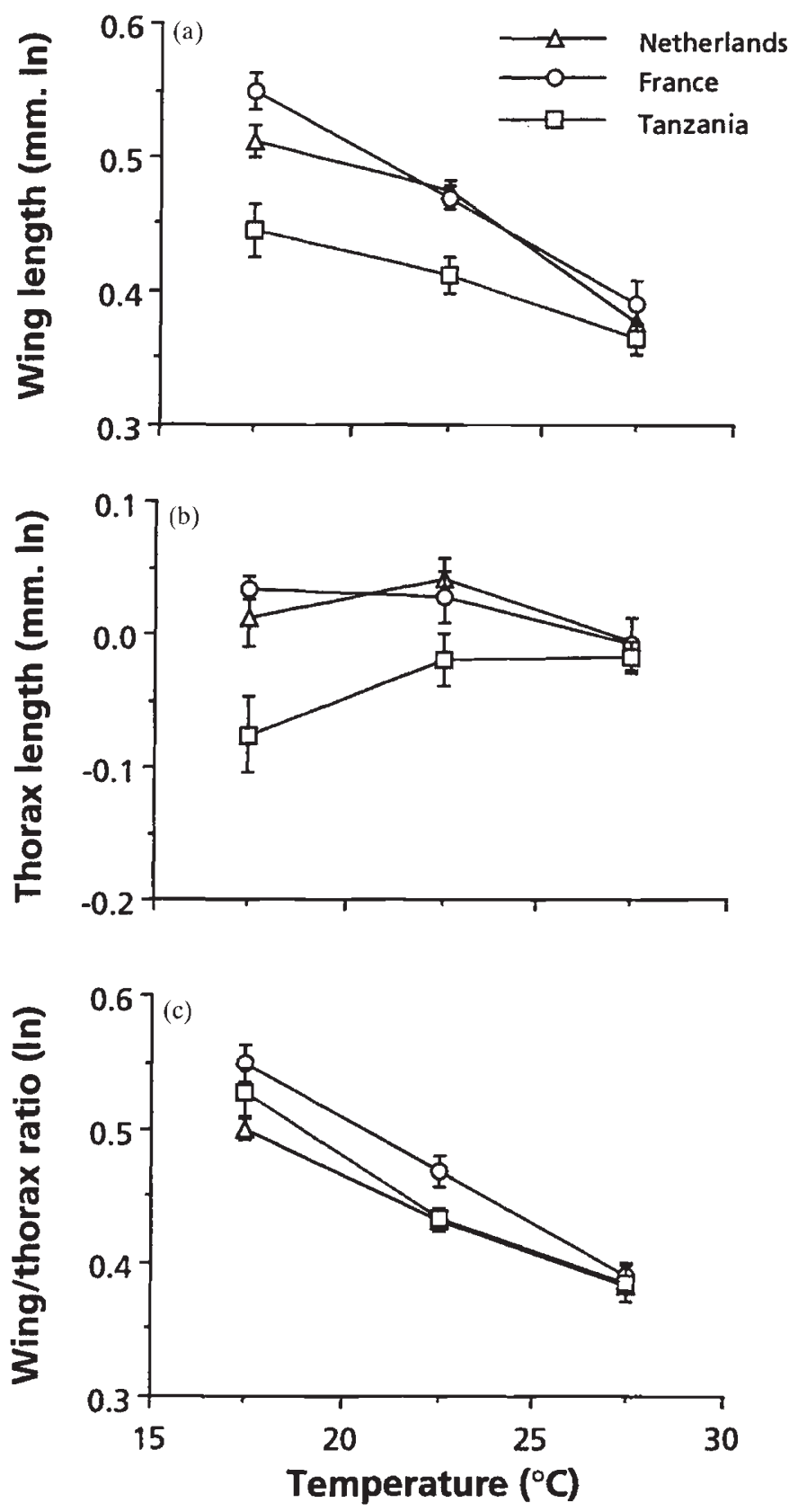

Fig. 1 Mean response $( \pm S E)$ per population of wing length (a), thorax length (b) and the wing-thorax ratio (c) to temperature for the initial 21 isofemale lines.

(C) The Genetical Society of Great Britain, Heredity, 79, 260-267. 


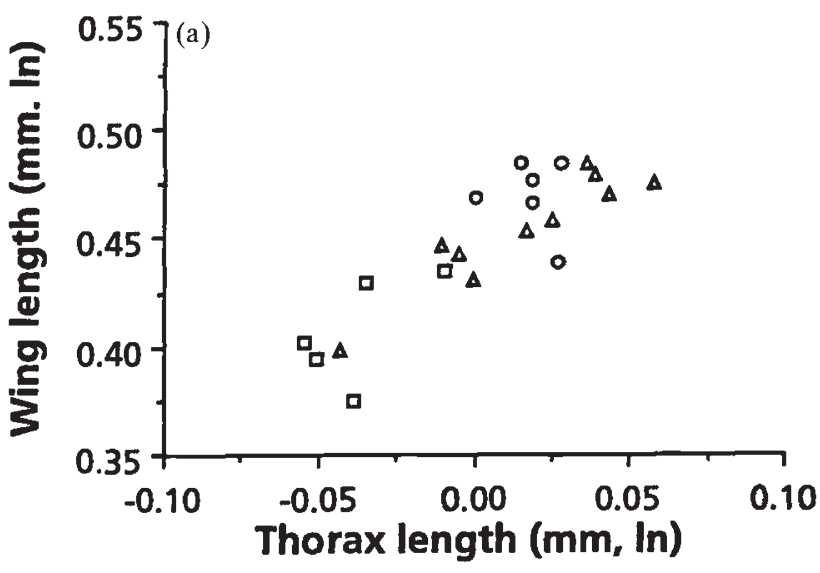

Table 1 Analysis of variance of wing length, thorax length and the wing to thorax ratio of an initial set of 21 lines from three populations raised at three temperatures

\begin{tabular}{|c|c|c|c|c|c|c|c|}
\hline \multirow[b]{2}{*}{ Source } & \multirow[b]{2}{*}{ d.f. } & \multicolumn{2}{|c|}{ Wing length } & \multicolumn{2}{|c|}{ Thorax length } & \multicolumn{2}{|c|}{$\mathrm{W} / \mathrm{T}$ ratio } \\
\hline & & MS & $F$ & MS & $F$ & MS & $F$ \\
\hline Temp & 2 & 40.05 & $124.74^{* * *}$ & 5.73 & $11.09 * * *$ & 59.27 & $226.45^{* * *}$ \\
\hline Population & 2 & 26.35 & $6.56^{* *}$ & 12.12 & $3.27 \dagger$ & 3.24 & 1.24 \\
\hline Line in $P$ & 18 & 4.02 & $12.51^{* * *}$ & 3.70 & $7.17^{* * *}$ & 2.60 & $9.94 * * *$ \\
\hline $\mathrm{T} \times \mathrm{P}$ & 4 & 1.41 & 0.72 & 4.30 & 1.32 & 1.21 & 1.06 \\
\hline $\mathrm{T} \times \mathrm{L}$ in $\mathrm{P}$ & 36 & 1.97 & $6.15^{* * *}$ & 3.26 & $6.31 * * *$ & 1.14 & $4.35 * * *$ \\
\hline Error & 95 & 0.32 & & 0.52 & & 0.26 & \\
\hline
\end{tabular}

Characters are ln-transformed. Population effect and population $\times$ temperature interaction are tested against the between-line and temperature $\times$ line MS.

Mean squares are presented multiplied by $10^{3}$. Significance level is indicated by symbols: $\dagger P<0.10,{ }^{*} P<0.05,{ }^{* *} P<0.01$ and ${ }^{* *} * P<0.001$.

\section{Cell size and cell number}

The mean responses to temperature of cell size and cell number for each population are presented in Fig. 3. Analysis of variance shows a significant differ-
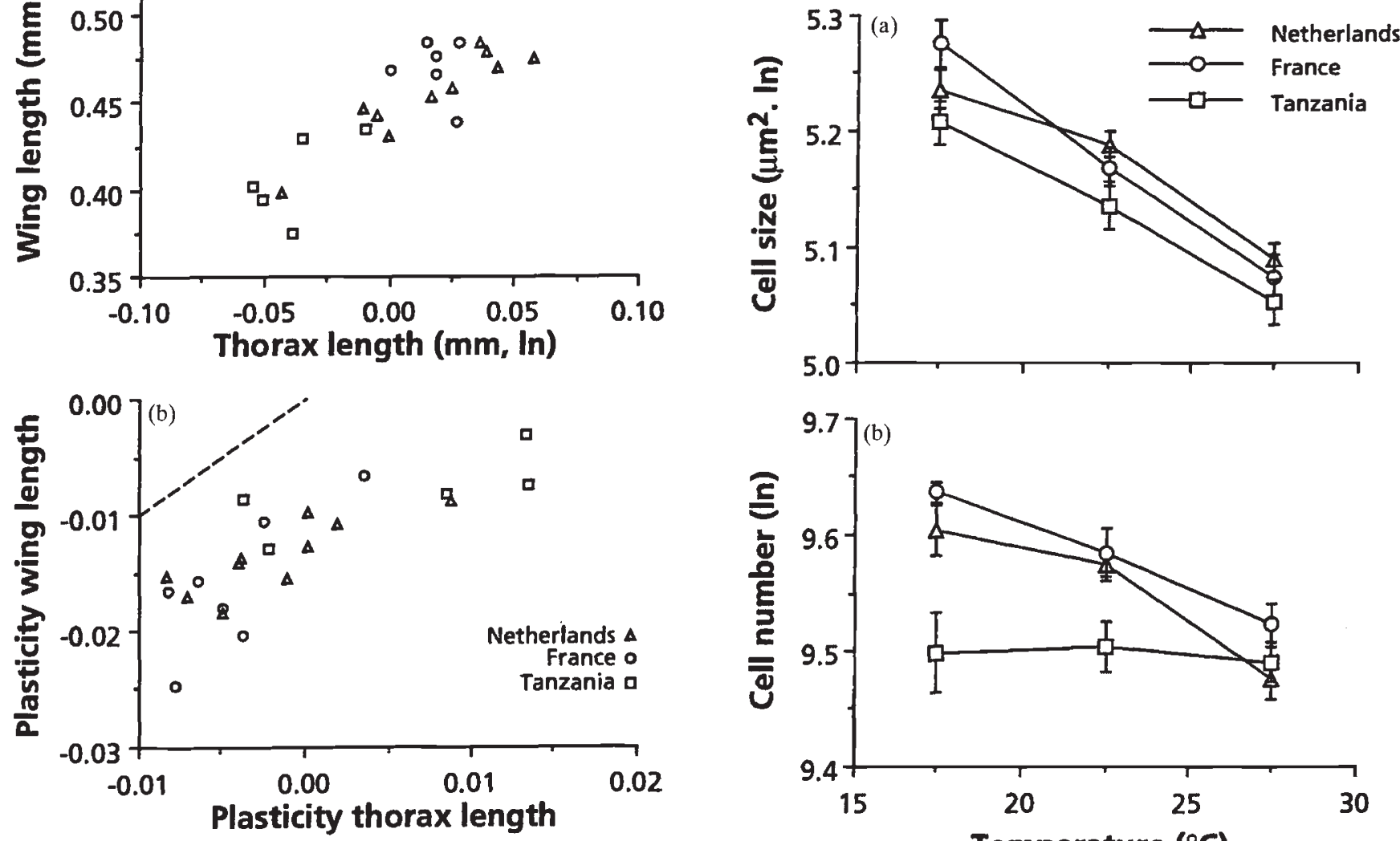

Fig. 2 Overall level (a) and plasticity (b) of reaction norms of wing length and thorax length for three populations of the initial 21 isofemale lines. Dotted line indicates line of equal plasticity in wing length and thorax length.

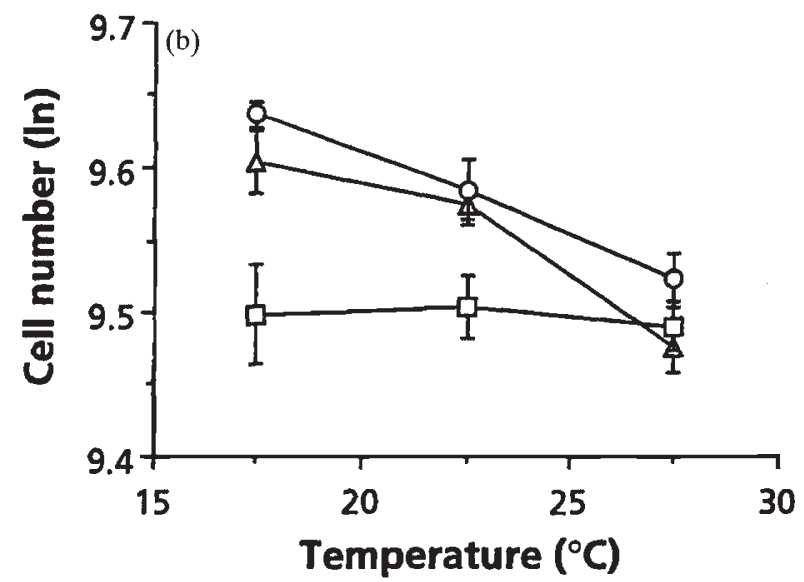

Fig. 3 Mean response $( \pm S E)$ per population of cell size (a) and cell number (b) to temperature for the initial 21 isofemale lines. 
Table 2 Analysis of variance of cell size and cell number (see Table 1 for further details)

\begin{tabular}{lrrcrcc}
\hline & & \multicolumn{2}{c}{ Cell size } & & \multicolumn{2}{c}{ Cell number } \\
\cline { 3 - 4 } \cline { 6 - 7 } Source & d.f. & \multicolumn{1}{c}{ MS } & $F$ & & MS & $F$ \\
\hline Temperature & 2 & 66.60 & $80.09^{* * *}$ & & 22.03 & $17.03^{* * *}$ \\
Population & 2 & 26.19 & $5.75^{*}$ & & 26.66 & 2.11 \\
Line in $\mathrm{P}$ & 18 & 4.55 & $5.48^{* * *}$ & & 12.61 & $9.75^{* * *}$ \\
$\mathrm{~T} \times \mathrm{P}$ & 4 & 0.90 & 0.19 & & 7.14 & 1.86 \\
$\mathrm{~T} \times \mathrm{L}$ in $\mathrm{P}$ & 36 & 4.82 & $5.79^{* * *}$ & & 3.85 & $2.97^{* * *}$ \\
Error & 95 & 0.83 & & & 1.29 & \\
\hline
\end{tabular}

Mean squares are presented multiplied by $10^{3}$. Level of significance is indicated by symbols: ${ }^{*} P<0.05$ and ${ }^{* * *} P<0.001$.

ence between populations for cell size (Table 2). No significant difference in cell number between populations could be shown because of the large variation between lines (Table 2). However, including the second set of lines in the analysis leads to a significant difference in cell number between populations $\left(F_{2,137}=6.08, P<0.01\right)$.

As is the case with wing size, cell size and cell number show substantial genetic variation within populations (Table 2). Significant genetic variation in plasticity could be shown for both characters (ANCOVA - cell size: $F_{18,116}=3.59, \quad P<0.001$; cell number: $\left.F_{18,116}=3.65, P<0.001\right)$.

\section{Cellular basis of overall wing size}

The cellular basis of the observed variation in wing size was analysed separately for the overall level and plasticity of the reaction norms. Overall cell size and overall cell number per line were plotted against overall wing size for both sets of lines (Fig. 4). Comparing the initial set of 21 lines with the seven lines raised for an additional 2 years at $17.5^{\circ} \mathrm{C}$, an increase in overall cell size and, to a lesser extent, wing area is observed. A similar increase in cell size was observed by Partridge et al. (1994) after keeping populations at low temperatures for a number of years.

After correction for differences in mean between the two sets of lines, the overall level of both cell size $(r=0.816, P<0.001)$ and cell number $(r=0.939$, $P<0.001)$ are correlated with the overall wing area. However, the regression of the relation with wing area is closer to one for cell number than for cell size, indicating a larger contribution of cell number to between-line variation in wing area compared with cell size (Fig. 4). Differences in wing area between populations follow this pattern, mainly differing in cell number.

\section{Cellular basis of plasticity}

The differences in plasticity of cell size, cell number and wing area all have a genetic basis (see above). To test the cellular basis of genetic variation in wing size plasticity $\left(W_{\mathrm{PL}}\right)$, it was plotted against the plasti-
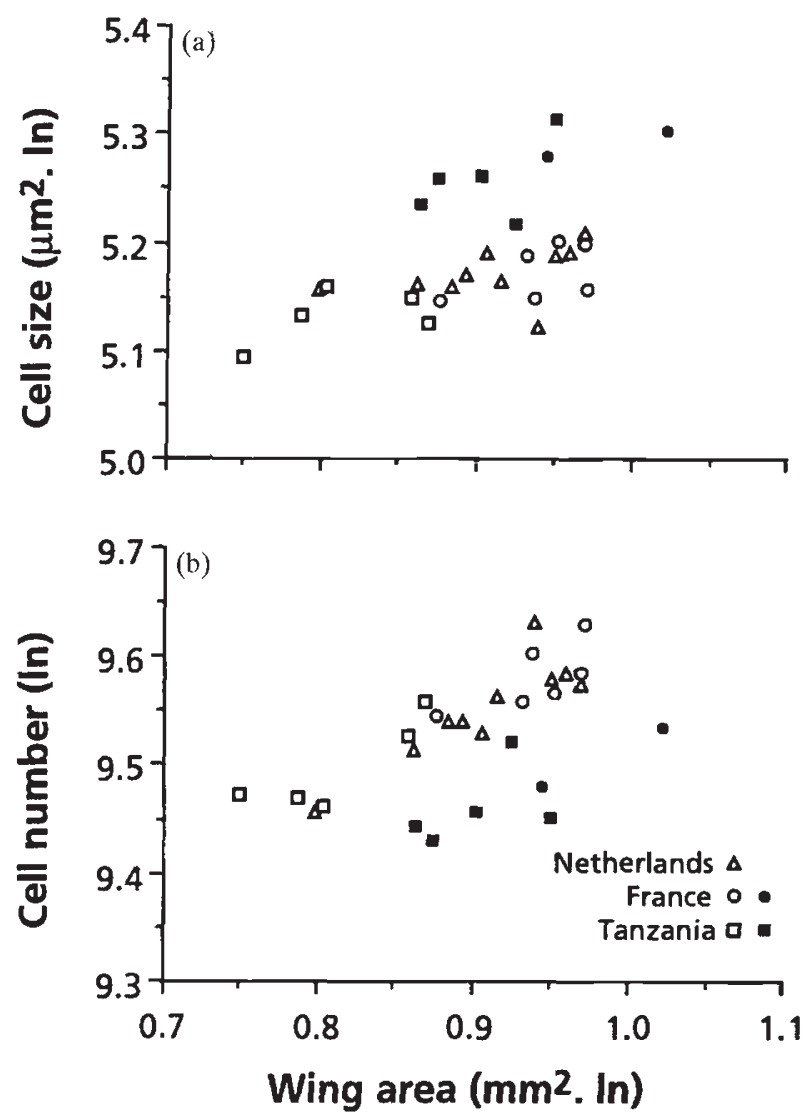

Fig. 4 Overall wing area plotted against overall cell size (a) and overall cell number (b) for three populations. Open circles are the initial set of lines; filled symbols represent additional lines raised for an additional 2 years at $17.5^{\circ} \mathrm{C}$ (see Materials and methods).

(c) The Genetical Society of Great Britain, Heredity, 79, 260-267. 
city in cell size and cell number (Fig. 5). The two sets of lines do not appear to differ markedly in plasticity and are therefore pooled. The relation between the plasticity of wing area with its cellular components appears to show two regions (Fig. 5). As a post hoc test, the relation between cell size plasticity and wing area plasticity was therefore analysed by fitting a linear regression, which is allowed to change slope once at any value of $W_{\mathrm{PL}}$ (spss nonlinear regression procedure; see legend to Fig. 5). This regression analysis showed a highly significant change in slope $(\delta b=0.994 \pm 0.212$, $P<0.001)$ at $W_{\mathrm{PL}}=-0.029$. In steep reaction norms $\left(W_{\mathrm{PL}}<-0.029\right)$, the slope of the regression of cell size plasticity to wing area plasticity is close to unity (see legend to Fig. 5), indicating a proportional rela-
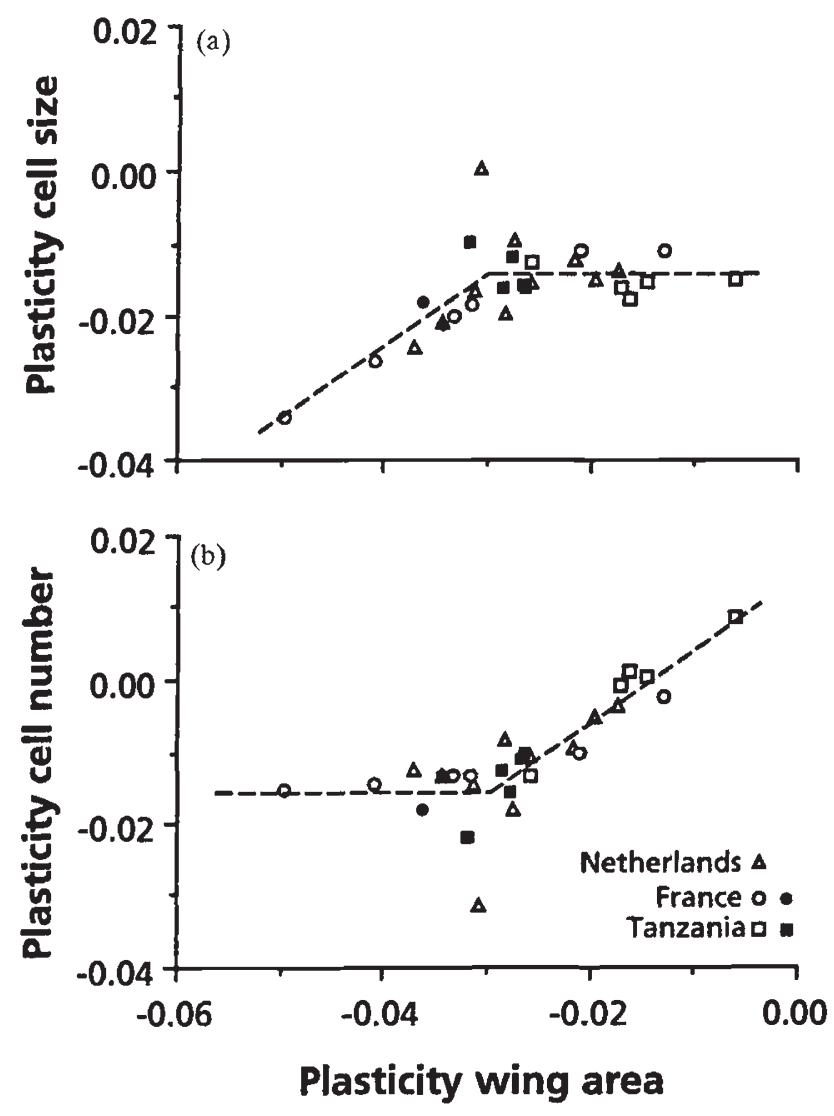

Fig. 5 Plasticity in cell size (a) and cell number (b) plotted against plasticity of wing area for three populations. Open circles are the initial set of lines; filled symbols represent additional lines raised for an additional 2 years at $17.5^{\circ} \mathrm{C}$ (see Materials and methods). Dotted line indicates continuous nonlinear regression line [cell size plasticity $\left(S_{\mathrm{PL}}\right): W_{\mathrm{PL}}=0.015+1.004 S_{\mathrm{PL}}$ for $W_{\mathrm{PL}}<-0.029$ and $W_{\mathrm{PL}}=-0.014+0.002 S_{\mathrm{PL}}$ for $W_{\mathrm{PL}} \geq-0.029$; the line presented for cell number follows directly from this relation). tion; the plasticity in cell number is relatively constant (Fig. 5b), and differences in wing area plasticity can be fully explained by differences in the plasticity in cell size. The reverse happens at less steep reaction norms of wing area $\left(W_{\mathrm{PL}}>-0.029\right)$, where the plasticity in cell size is relatively constant (Fig. 5a). Here, wing area plasticity is determined by the plasticity in cell number (Fig. 5b). This pattern indicates that the variation in plasticity in cell size and cell number is restricted, with cell size showing a minimum in slope and cell number a maximum in slope (Fig. 5). The main deviation from this pattern is one line from The Netherlands, showing no plasticity in cell size. This one line, which was excluded from the regression analysis, does not affect the conclusions of the analysis.

The Tanzanian lines show a limited plasticity in wing area (Fig. 1) at or above the transition point (Fig. 5), although well within the general scope of genetic variation in plasticity. However, the transition from cell size- to cell number-determined wing area plasticity can be observed between lines within the French and Dutch populations. This indicates that the observed pattern is not caused by betweenpopulation differences, but is generated by a more general mechanism.

\section{Cell size and relative wing size}

Variation in wing size can only be partly attributed to variation in the general size of the lines (see above). Wing size variation is partly caused by changes in the relative size of the wing compared with thorax length. To determine the cellular basis of the genetic differences in relative wing size, the partial correlation coefficient between cell size, cell number and wing length, controlling for thorax length, was determined. Reaction norms were analysed for overall level and plasticity separately.

A significant partial correlation could be shown only between overall wing length and overall cell number, not with overall cell size (cell size: $r_{\text {ws.t }}=0.199$, NS; cell number: $r_{\text {wn.t }}=0.542$, $P=0.003$ ). This result shows that variation in the relative overall wing size is caused mainly by variation in cell number. The significant correlation between overall cell size and overall wing size $(r=0.817, P=0.001)$ disappears after correction for thorax length, indicating that overall cell size mainly affects overall wing area by changing the general size of the animal.

In contrast, plasticity in wing size shows only a significant partial correlation with the plasticity in cell size, but not with the plasticity in cell number 
(cell size: $r_{\text {ws.t }}=0.661, \quad P<0.001$; cell number: $\left.r_{\text {wn.t }}=0.310, \mathrm{NS}\right)$. This result shows that genetic variation in the plasticity of relative wing size is mainly caused by differences in the plasticity of cell size.

\section{Discussion}

The cellular basis of wing size plasticity depends on the slope of the response. In steep reaction norms of wing size, differences in slope are accomplished by different plasticities of cell size, whereas cell number plasticity remains similar over lines at its maximum slope (Fig. 5). However, in the less steep reaction norms for wing size, the plasticity in cell size remains the same over lines at its minimum slope; differences in these wing size plasticities result from different plasticities of cell number. The transition from cell size- to cell number-determined plasticity in wing size indicates that the plasticities in cell size and cell number do not vary independently, but originate from a common mechanism.

The present study indicates why previous studies found divergent patterns in the way plasticity in cell size and plasticity in cell number influence wing area plasticity. Most authors agree on the dominance of the effect of cell size (e.g. Alpatov, 1930; Robertson, 1959; Cavicchi et al., 1985; Partridge et al., 1994). However, the contribution of cell number to changes in wing size varies between different experiments. The present experiment shows the presence of substantial genetic variation between lines in the response of cell number, encompassing the whole range of responses observed in earlier studies (Fig. $5)$.

The observed co-gradient variation in wing size (Tantawy \& Mallah, 1961; Coyne \& Beecham, 1987) suggests a lower limit to the plasticity of wing size (see Introduction). This study indicates that the plasticity in wing size can only be increased by increasing the plasticity of cell size. A limit to the plasticity of wing size could be generated by a maximum in the plasticity of cell size. Changes in cell size in response to temperature can be caused by changes in cell volume or in the level of cell flattening. Wing size is highly sensitive to temperature during the early pupal stages (Pantalouris, 1957), mainly affecting cell size (Masry \& Robertson, 1979). During the early pupal stages, evagination of the imaginal discs occurs. Cell flattening is the major morphogenetic process during evagination of the wing discs (Fristrom et al., 1977), partly determining final wing size and shape (Gonzales-Gaitan et al., 1994). Kuo \& Larsen (1987) showed that wing thickness, consisting of two cell layers, is highly affected by temperature conditions, showing an opposite trend compared with cell area. These observations suggest that cell flattening is an important mechanism in the response to temperature. However, the level of cell flattening might be limited, ensuring sufficient robustness of the wing to withstand the forces imposed on the wing during flight. This negative relation between wing size and wing thickness might constrain the response to temperature-mediated selection.

Plasticity in wing length and thorax length are correlated (Fig. 2b), indicating that a large part of the variation in plasticity involves changes in general size. However, a small but significant fraction of the variation in wing length plasticity leads to variation in the plasticity of the wing-thorax ratio, as observed in a number of studies (Table 2; e.g. David et al., 1994). The reduction of the wing-thorax ratio with temperature might be an adaptive response, adapting wing loading to the increased power of the flight muscles at higher air temperatures (Reed $e t$ al., 1942; David et al., 1994). The adaptiveness of the response seems to be confirmed by the observed clinal variation in wing-thorax ratio (e.g. Capy et al., 1993; James et al., 1995). Higher wing-thorax ratios are found in populations from higher latitudes, generally associated with lower temperatures. It was found that variation in the response of the wingthorax ratio to temperature is mainly related to the response of cell size rather than cell number. Selection on the plasticity of the wing-thorax response might lead to a correlated response in the plasticity of cell size and wing size.

Temperature treatment during the early pupal stages, affecting cell size by changing the level of cell flattening (Kuo \& Larsen, 1987), has little effect on thorax size, thereby changing the wing-thorax ratio (Pantalouris, 1957; Masry \& Robertson, 1979). Genetic variation in the level of cell flattening might, therefore, lead to a genetic correlation of wing size plasticity, through cell size, with the plasticity of the wing-thorax ratio. This hypothesis stresses the importance of studying cell thickness and wing thickness for understanding the mechanisms responsible for the response of wing size to temperature and the evolution of wing size under varying temperature conditions.

\section{Acknowledgements}

We would like to thank Dr Maarten Terlouw for his assistance in using the IBAS image analyser, and Cas Kruitwagen for his advice on the statistical analyses. This study was supported by The Nether- 
lands Organization for Scientific Research (NWO grant 805.36.187).

\section{References}

ANDERSON, w. w. 1966. Genetic divergence in M. Vethukhiv's experimental populations of Drosophila pseudoobscura. 3. Divergence in body size. Genet. Res., 7, 255-266.

alpatov, w. w. 1930. Phenotypic variation in body and cell size of Drosophila melanogaster. Biol. Bull., 58, $85-103$.

BERVEN, K. A., GILL, D. E. AND SMITH-GILl, s. J. 1979. Countergradient selection in the green tree frog, Rana clamitans. Evolution, 33, 609-623.

CAPY, P., PLA, E. AND DAVID, J. R. 1993. Phenotypic and genetic variability of morphometrical traits in natural populations of Drosophila melanogaster and D. simulans. I. Geographic variations. Génét. Sél. Evol., 25, 517-536.

CAVICCHI, s., GUERRA, D., GIORGI, G. AND PEZZOLI, C. 1985. Temperature-related divergence in experimental populations of Drosophila melanogaster. I. Genetic and developmental basis of wing size and shape variation. Genetics, 109, 665-689.

COYNE, J. A. AND BEECHAM, E. 1987. Heritability of two morphological characters within and among natural populations of Drosophila melanogaster. Genetics, 117, $727-737$.

DAVID, J. R., ALLEMAND, R., VAN HERREWEGE, J. AND COHET, Y. 1983. Ecophysiology: abiotic factors. In: Ashburner, M., Carson, H. L. and Thompson, J. N., Jr (eds) The Genetics and Biology of Drosophila, Vol. 3d, pp. 106-154. Academic Press, London.

DAVID, J. R., MORETEAU, B., GAUTHIER, J. P., PÉTAVy, G., STOCKEL, A. AND IMASHEVA, A. G. 1994. Reaction norms of size characters in relation to growth temperature in Drosophila melanogaster: an isofemale lines analysis. Génét. Sél. Evol., 26, 229-251.

DOBZHANSKY, TH. 1928. The influence of the quantity and quality of chromosomal material on the size of the cells in Drosophila melanogaster. W. Roux' Archiv. Entwicklungsmech., 115, 363-377.

FRISTROM, J. W., FRISTROM, D. K., FEKETE, E. AND KUNIYUK1, A. H. 1977. The mechanism of evagination of imaginal discs of Drosophil. melanogaster. Am. Zool., 17, 671-684.

GONZALEZ-Gaitan, M., PAZ CAPDEVIla, M. AND GaRCiABELLIDO, A. 1994. Cell proliferation patterns in the wing imaginal disc of Drosophila. Mech. Dev. , 40, 183-200.

JAMES, A. C., AZEVEDO, R. B. R. AND PARTRIDGE, L. 1995. Cellular basis and developmental timing in a size cline of Drosophila melanogaster. Genetics, 140, 659-666.
KUO, T. AND LARSEN, E. 1987. The cellular basis of wing size modification in Drosophila: the effect of the miniature gene, crowding, and temperature. Devl. Genet., 8 , 91-98.

LEVINS, R. 1968. Evolution in Changing Environments. Princeton University Press, Princeton.

MASRY, A. M. AND ROBERTSON, F. W. 1979. Cell size and number in the Drosophila wing. III. The influence of temperature differences during development. Egypt $J$. Gen. Cyt., 8, 71-79.

MAYNARD SMITH, J. M., BURIAN, R., KAUFFMAN, S., ALbERCh, P., CAMPBell, J. AND GOODMAN, B. 1985. Developmental constraints and evolution. Q. Rev. Biol., 60, 265-287.

NOACH, E. J. K., DE JONG, G. AND SCHARLOO, w. 1996. Phenotypic plasticity in morphological traits in two populations of Drosophila melanogaster. J. Evol. Biol., 9, 831-844.

PANTALOURIS, E. M. 1957. Size response of developing Drosophila to temperature changes. J. Genet., 55, 507-510.

PARTRIDGE, L., BARRIE, B., FOWLER, K. AND FRENCH, V. 1994. Evolution and development of body size and cell size in Drosophila melanogaster in response to temperature. Evolution, 48, 1269-1276.

REED, S. C., WILliams, C. M. AND CHADWICK, L. E. 1942. Frequency of wing beat as a character for separating species races and geographic varieties of Drosophila. Genetics, 27, 349-361.

ROBERTSON, F. W. 1959. Studies in quantitative inheritance. XII. Cell size and number in relation to genetic and environmental variation of body size in Drosophila. Genetics, 44, 869-896.

SANG, J. H. 1956. The quantitative nutritional requirements of Drosophila melanogaster. J. Exp. Biol., 33, 45-72.

SCHARLOO, w. 1987. Constraints in selection response. In: Loeschcke, V. (ed.) Genetic Constraints on Adaptive Evolution, pp. 125-150. Springer, Berlin.

SCHARLOO, w. 1990. The effect of developmental constraints on selection response. In: Maynard Smith, J. and Vida, G. (eds) Organizational Constraints on the Dynamics of Evolution, pp. 197-210. Manchester University Press, Manchester.

SCHEINER, S. M. AND LYMAN, R. F. 1991. The genetics of phenotypic plasticity. II. Response to selection. J. Evol. Biol., 4, 23-50.

SOKAL, R. R. AND ROHLF, F. J. 1981. Biometry, 2nd edn. Freeman, New York.

SPSS INC. 1992. SPSS/PC+Base Manual version 4.0. SPSS, Chicago.

TANTAWY, A. O. AND Mallah, G. s. 1961. Studies on natural populations of Drosophila. I. Heat resistance and geographic variation in Drosophila melanogaster and D. simulans. Evolution, 15, 1-14. 